\title{
Relacje polsko-ukraińskie na Wołyniu w dwudziestoleciu międzywojennym. „Kilka uwag z powodu naszej klęski wyborczej na Wołyniu" (1922 r.)
}

Zamieszczony poniżej dokument, stworzony przez polskiego działacza społeczno-politycznego na Wołyniu w okresie międzywojennym, stanowi wkład do popularyzacji wiedzy na temat relacji polsko-ukraińskich w regionie przez wybuchem II wojny światowej. Źródło zostało opublikowane w dosłownym brzmieniu. Treść przedstawia krytykę polskiej polityki prowadzonej wobec ludu ukraińskiego na Wołyniu. Autor podsumował postępowanie strony polskiej, które doprowadziło do sromotnej klęski w wyborach do sejmu i senatu w 1922 r. Poruszające są szczegółowa analiza polskich „przewin” wobec Ukraińców, zrozumienie szkód, jakie powstały na ich skutek, oraz potrzeba roztropnego działania w celu uzdrowienia sytuacji. Piszący ten memoriał był doskonale zorientowany $\mathrm{w}$ stosunkach ludnościowych panujących na ziemi wołyńskiej. Z perspektywy współczesnego badacza zadziwia dalekowzroczność autora dokumentu oraz ocena, jakiej dokonał. Można powiedzieć, że człowiek ten przewidział ewentualne konsekwencje polityki antyukraińskiej, jaką prowadził rząd warszawski. Warto zwrócić uwagę na przenikliwość wywodu zawartego w przedstawionym materiale archiwalnym. Autokrytyka po stronie polskiej nie była ówcześnie częstym zjawiskiem, co nadaje źródłu dodatkowy walor.

Nie skupiam się tu na omawianiu stosunków polsko-ukraińskich na Wołyniu, gdyż temat ten doczekał się wielu opracowań naukowych i popularnonaukowych ${ }^{1}$. Warto jednak przed lektura zamieszczonego źródła zapoznać się ze specyfiką stanu ludności na Wołyniu w II RP.

\footnotetext{
${ }^{1}$ Polska - Ukraina. Dziedzictwo i wspótczesność, red. R. Drozd, T. Sucharski, Słupsk 2012; Polska, Ukraina, świat, red. K. Budzowski, A. Demianczuk, Kraków 2005; W. Pestka, Do
} 
Ogólnie w granicach odrodzonej Polski mieszkało ok. 4441006 Ukraińców, czyli $13,9 \%$ wszystkich obywateli państwa. Sa to oczywiście oficjalne dane ze spisu powszechnego z 1931 r., niewolne od błędów (przyjęto kryterium językowe). Ludność ukraińska zdecydowanie przeważała w województwach: stanisławowskim, tarnopolskim i wołyńskim ${ }^{2}$. W województwie lwowskim Polacy stanowili 57,7\% ogółu mieszkańców, Ukraińcy zaś 18,5\% (22\% wskazało język „ruski”) ${ }^{3}$.

W samym województwie wołyńskim w 1921 r. mieszkało ogólnie 1578000 ludzi, z czego ok. 1087000 Ukraińców, Polaków zaś ok. 266 000. Do 1931 r. dane te uległy zmianie. Wołyń zamieszkiwało ogółem 2086000 osób, z czego ok. 1418000 Ukraińców i 347000 Polaków. Włodzimierz Mędrzecki wyliczył, że w 1921 r. w województwie wołyńskim było ok. 1134000 Ukraińców, a Polaków $191000^{4}$. W ciagu 10 lat znacznie wzrosła liczba ludności Wołynia o 1/3, niemal 514 000. Był to wynik wysokiego przyrostu naturalnego oraz dodatniego bilansu ruchów migracyjnych, ok. 104000 ludzi. Tysiące Ukraińców wracało do swych domów po wysiedleniach w czasie I wojny światowej. W grupie repatriantów dominowała ludność ukraińska, Polacy i Niemcy zaś byli w mniejszości ${ }^{5}$.

W wyniku przemian społecznych i politycznych, przesiedleń i doświadczeń wojennych silnie rozwiną się wśród Rusinów duch nacjonalizmu. Nie bez znaczenia była działalność Ukraińców, którzy służyli w armii austriackiej i okupowali Wołyń po wyparciu Rosjan (1915 r.). Wtedy też aktywną agitację na rzecz ukraińskiej świadomości narodowej podjęli ukraińscy działacze społeczni z Galicji. Odrębność narodowa Ukraińców została również wzmocniona, gdy od 1918 do 1919 r. na Wołyniu stacjonowały wojska Ukraińskiej Centralnej Rady i Ukraińskiej Republiki Ludowej. W tym czasie działała

zobaczenia $w$ piekle. Kresowa apokalipsa: Ukraina, Polska, Białoruś, Eotwa, Warszawa 2009; J. Konieczna-Sałamatin, Polska, Ukraina. Wzajemny wizerunek, Warszawa 2001; L. Karłowicz, Polska - Ukraina. Smutne refleksje, Lublin 2002; Polska - Ukraina. Pogranicze kulturowe i etniczne, red. J. Kamocki i in., Wrocław 2008; Polska-Ukraina: historia, polityka, kultura. Materiaty międzynarodowej konferencji naukowej, red. S. Zabrowarny, Warszawa 2003; M. Mróz, W kręgu dyplomacji watykańskiej. Rosja, Polska, Ukraina $w$ dyplomacji watykańskiej w latach 1917-1926, Toruń 2004.

${ }^{2}$ P. Eberhardt, Między Rosja a Niemcami. Przemiany narodowościowe w Europie Środkowo-Wschodniej $w X X$ w., Warszawa 1996, s. 102-103.

${ }^{3}$ D. Skoczek, Struktura narodowo-wyznaniowa Kresów Wschodnich w Drugiej Rzeczypospolitej. Zarys problematyki, „Prace Naukowe Akademii im. Jana Długosza w Częstochowie” 2010, z. 11, s. 354. Polacy stanowili także większość w powiecie sałackim w województwie tarnopolskim. Zob. G. Hryciuk, J. Stoćkyj, Studia nad demografia historyczna i sytuacja religijna Ukrainy, Lublin 2000, s. 16.

${ }^{4}$ W. Mędrzecki, Województwo wotyńskie 1921-1939. Elementy przemian cywilizacyjnych, społecznych i politycznych, Wrocław 1988, s. 69-71.

${ }^{5}$ G. Hryciuk, Przemiany narodowościowe i ludnościowe $w$ Galicji Wschodniej $i$ na Wotyniu w latach 1931-1948, Toruń 2005, s. 138-139. 
niezależna administracja ukraińska - namiastka własnego państwa ${ }^{6}$. Jak pisał Jerzy Tomaszewski, „Zbyt słabo uświadamiamy sobie konsekwencje faktu, że społeczność ukraińska znalazła się w granicach Polski wbrew swej woli, w wyniku klęski wojennej. W latach międzywojennych nie dostrzegał tego chyba nikt z Polaków zabierających głos w kwestii ukraińskiej. Przede wszystkim była to klęska Zachodnio-Ukraińskiej Republiki Ludowej”’

Po włączeniu siłą ziem Galicji Wschodniej i Wołynia do Polski i likwidacji zaczątków państwowości ukraińskiej ludność rdzenna tych ziem była wrogo nastawiona do rządu polskiego. Większość ukraińskich partii politycznych negowała polską władzę i była nastawiona opozycyjnie. Należy dodać, że wybory z roku 1919 r. na ziemiach ukraińskich nie odbyły się. Natomiast w 1922 r. wybory do sejmu i senatu zbojkotowały ukraińskie partie nacjonalistyczne, udział wzięła tylko część Ukraińców. W rezultacie przedstawiciele ukraińscy w parlamencie byli niewielką grupa, która obejmowała 20 posłów. Wkrótce 5 wystapiło, a kolejnych 4 przeszło do frakcji komunistycznej ${ }^{8}$.

Biorąc pod uwagę wyniki wyborów w samych województwach, największą klęskę Polacy ponieśli w województwie wołyńskim, gdzie mniejszości narodowe zdobyły 16 mandatów. Ludność ukraińska masowo głosowała na listę nr 16, czyli Blok Mniejszości Narodowych. Właśnie ten stan rzeczy po wyborach na Wołyniu przeanalizował w przedstawionym poniżej źródle ziemianin i przyszły burmistrz Łucka.

Prezentowany dokument składa się z ośmiu kart formatu A4, jest to maszynopis. Na dole ostatniej karty widnieje odręczny podpis zgodny z podpisem wykonanym na maszynie do pisania ponad nim. Brak innych adnotacji i pieczęci. Tekst źródła został przedstawiony w oryginalnym brzmieniu. Przypisami opatrzono terminy wymagające wyjaśnienia: wyrazy obcojęzyczne, skróty, nazwy własne, osoby itd.

Mateusz Pielka

Bydgoszcz

\footnotetext{
${ }^{6}$ W. Mędrzecki, op. cit., s. 81.

7 J. Tomaszewski, Ojczyzna nie tylko Polaków. Mniejszości narodowe w Polsce $w$ latach 1918-1939, Warszawa 1985, s. 57. Autor dalej pisał: „Krótkotrwałe jej dzieje [Zachodnioukraińskiej Republiki Ludowej] są u nas zupełnie nieznane, a przecież państwo to nie było fikcja, zdołało w ciagu niewielu miesięcy stworzyć armię, administrację, podjęło wstępne działania na arenie międzynarodowej, usiłując uzyskać akceptację swego istnienia. Wprawdzie nie zdołało tego osiagnaćc, lecz przecież nawiązało faktyczne stosunki gospodarcze z sąsiednimi krajami. W literaturze polskiej o państwie tym pisano z reguły źle, często bardzo źle, ukazując wyłącznie chaos i okrucieństwo Ukraińców, gloryfikując szlachetność i bohaterstwo Polaków”.

${ }^{8}$ H. Zieliński, Historia Polski 1914-1939, Wrocław 1982, s. 138.
} 


\section{„Kilka uwag z powodu naszej klęski wyborczej na Wołyniu"}

Wybory na Wołyniu do Sejmu i Senatu Rzeczypospolitej zakończyły się ciężka i najpełniejszą klęską zarówno dla Rządu, jak i dla społeczeństwa polskiego ${ }^{10}$.

16 posłów $^{11} \mathrm{z}$ bloku mniejszości narodowych ${ }^{12}$, mających reprezentować interesy ludności Wołynia ${ }^{13}$, z pominięciem społeczeństwa polskiego, które reprezentanta swojego ani w Sejmie ani w Senacie mieć nie będzie, w gruncie rzeczy nie sa wyrazicielami potrzeb ludu ukraińskiego, zamieszkującego kraj tutejszy w głównej, przemożnej masie, są jednak bezsprzecznie wymownym wyrazem nieprzyjaznego a nawet wrogiego nastroju tej ludności w stosunku do Państwa, Rządu i społeczeństwa polskiego ${ }^{14}$.

Polacy na Wołyniu na tak wysoce niepomyślny i złowrogi rezultat wyborów patrza zbyt powierzchownie, a reagują zbyt uczuciowo. Klęskę przypisuje się z jednej strony swojemu rozbiciu, które na podstawie zestawienia cyfr nie odegrało jednak decydującej roli, z drugiej zaś - potędze środków agitacyjnych bloku mniejszości narodowych. Boleje się więcej raczej nad obrażoną miłościa własną i zawiedzionemi nadziejami stronnictw, partji i osób, niż nad klęska Państwa i jego stanowiska na Wołyniu.

Przedstawiciele Rządu, którzy tak bezkrytycznie różowo patrzyli na sprawę wyborów i dla których tak wyjątkowo jednolite i potężne zwycięstwo listy Nr. 16 okazało się zupełną niespodzianka, nie daja gwarancji należycie głębokiego i wszechstronnego ocenienia powyższego zjawiska.

${ }^{9}$ Archiwum Akt Nowych, Kancelaria Cywilna Naczelnika Państwa w Warszawie, Wybory do Sejmu Ustawodawczego (przebieg i otwarcie Sejmu), 31, k. 217-224.

${ }^{10}$ Wybory do sejmu odbyły się 5 XI 1922 r., do senatu zaś 12 dnia tegoż miesiąca.

${ }^{11} \mathrm{~W}$ województwie wołyńskim przedstawiciele Bloku Mniejszości Narodowych uzyskali 16 mandatów. Zob. E. Mietlicz, Geografia polityczna Kresów Wschodnich w latach 1922-1930, „Annales Universitatis Mariae Curie-Skłodowska” 1999, t. VI, s. 180.

12 Blok Mniejszości Narodowych było to porozumienie polityczne mniejszości narodowych II RP (Ukraińcy, Żydzi, Niemcy i Białorusini). Formacja wystartowała w wyborach do sejmu i senatu w 1922 r., odnosząc znaczny sukces 15,1\% (66 mandatów). Sojusz funkcjonował do 1928 r. W wyborach Blok Mniejszości Narodowych występował jako lista nr 16.

${ }^{13}$ Część ziem wołyńskich przypadła Polsce na mocy traktatu ryskiego z 18 III 1921 r. Niebawem w tym samym roku utworzono województwo wołyńskie ze stolica w Łucku. Wołyń zamieszkiwało 983595000 Ukraińców, czyli 68,4\% wszystkich mieszkańców województwa. Zob. M. Rudnicka, Struktura demograficzna i społeczno-zawodowa mniejszości ukraińskiej $w$ Polsce, „De Securitate et Defensione” 2015, nr 1, s. 136.

${ }^{14}$ Partie ukraińskie z Galicji Wschodniej, które popierały rząd Zachodnioukraińskiej Republiki Ludowej pod przewodnictwem Jewhena Petruszewycza (przebywającego na emigracji w Wiedniu), zbojkotowały wybory, nie uznając tym samym władzy polskiej ani nie utożsamiając się z Polska. Inaczej postapiła ludność ukraińska zamieszkująca ziemie dawnego zaboru rosyjskiego, wzięła aktywny udział w wyborach (Wołyń). Zob. E. Koko, PPS wobec kwestii ukraińskiej w okresie wyborów do Sejmu i Senatu oraz na prezydenta Rzeczypospolitej w 1922 r., „Studia z Dziejów ZSRR i Europy Środkowej” 1990, t. XXV, s. 95-97. 
A tymczasem zjawisko to jest poważne, groźne i zastanawiające każdego obywateli, który potrafi patrzeć w przyszłość i wysnuwać odpowiednie wnioski z przeszłości i który zdaje sobie sprawę z tego, że niebezpieczeństwo jest bliskie i że trzeba mu zaradzić natychmiast i w sposób radykalny. Z powyższych względów, jako ten, który, od lat dwóch pracując na Wołyniu na gruncie polityczno-społecznym, potrafił $\mathrm{w}$ swoim czasie naszą klęskę obecna przewidzieć i który co do niej ostrzegał miejscowe społeczeństwo i czynniki rządowe, uważam za swój obowiązek niniejsze uwagi w tej sprawie przedłożyć do rozważenia.

Rezultat wyborów na Wołyniu jest nieubłaganie logicznem następstwem naszej bezprogramowej polityki kresowej, zainaugurowanej od chwili zamianowania na jesieni r. 1920 „Zarządu Tymczasowego Terenów Przyfrontowych i Etapów"15 i prowadzonej następnie przez nasze Ministerstwa i ich miejscowe organy wykonawcze, jak również - następstwem działalności na obszarze Wołynia naszych partji politycznych. Rezultat ten jest bardzo zastanawiającym co do swojej solidarności protestem ludu ukraińskiego na Wołyniu, i ta właśnie solidarność, ta bezprzykładna karność, z jaką lud poszedł pod komendę przywódców listy Nr. 16 jest w zjawisku tem sprawą najgroźniejsza. Protest $^{16}$ ten świadczy o znacznie większem uświadomieniu politycznem mas ludowych, niż się to czynnikom rządowym i społecznym wydawało, protest ten jest ryczałtowem potępieniem naszego programu politycznego na Wołyniu, oraz działalności naszych władz państwowych i partji politycznych. Nade wszystko zaś jest ten rezultat następstwem nieskoordynowania środków wykonawczych i taktyki z programem politycznym jaki został nakreślony, dwulicowości i wprost niedopuszczalnego zastosowania miękkich środków

15 Urząd utworzony na podstawie rozkazu Józefa Piłsudskiego z 9 IX 1920 r. Od 15 IX 1920 r. podlegał on ministrowi spraw wewnętrznych. 20 grudnia tego samego roku „Zarząd Tymczasowy Terenów...” został zlikwidowany. W swej istocie była to struktura administracji cywilnej, obejmująca tereny wschodnie byłego zaboru rosyjskiego. Zob. „Dziennik Urzędowy Zarządu Terenów Przyfrontowych i Etapowych", 18 XI 1920, nr 4, s. 1, http://prawo.sejm. gov.pl/isap.nsf/DocDetails.xsp?id=WDU19201150762 (dostęp: 15 IV 2019).

${ }^{16}$ Ukraińcy czuli się skrzywdzeni przez Polaków, gdyż ci ignorowali ich dążenia narodowe i polityczne przez wiele dekad. Szczytem kryzysu była walka o Lwów chwilę po I wojnie światowej. Granica Galicji Wschodniej została uznana przez Radę Ambasadorów Ententy dopiero 15 III 1923 r. Po tej dacie władze polskie mogły potraktować każdy polityczny sprzeciw Ukraińców za zdradę państwa. W związku z tym wielu Ukraińców doznało okrutnych represji. Na Wołyniu świadomość narodowa ludności ukraińskiej była nieco mniejsza, przez co Polacy ignorowali lokalną ludność. Ukraińców wołyńskich dyskryminowano, jeśli chodzi o zatrudnienie $\mathrm{w}$ administracji państwowej, szkolnictwie, zakupie ziemi itd. Na przykład na początku 1923 r. w województwie wołyńskim było 283 urzędników (w zarządach powiatowych i wojewódzkich), z czego 274 Polaków. Lokalna ludność zupełnie się z nimi nie identyfikowała. Polacy zaś popierali jedynie interesy polskich osadników. Ukraińscy historycy pisali o tym okresie jako o „reżimie polskim”, który miał cechy autorytarne. Więcej zob. E. Mironowicz, Białorusini i Ukraincy w polityce obozu pitsudczykowskiego, Białystok 2007, s. 129; https://www.istpravda.com.ua/articles/2011/02/3/21714/ (dostęp: 15 IV 2019). 
i sposobów rządzenia do ciężkiego i krzywdzącego tutejszy lud programu, nakreślonego przez źle zrozumiana polską rację stanu.

Bezsprzecznie blok mniejszości narodowych na Wołyniu rozporządzał kolosalnymi środkami finansowymi i technicznymi, którym my przeciwstawiliśmy bardzo watty aparat wyborczy. Gdybyśmy jednak wyprowadzili stosunek procentowy pomiędzy ich siła wyborczą i naszą i gdybyśmy sprawdzili, czy zdołaliśmy oderwać od listy Nr. 16 odpowiednią ilość głosów na nasze listy, to okazałoby się, że nie oderwaliśmy prawie nic, a przeciwnie - że na listę Nr. 16 padła pewna część i naszych polskich głosów - nastrój ludności. Czynnik ten został znakomicie wyzyskany przez blok mniejszości narodowych, któremu my sami przez nasza niezdarną bezprogramowa i pełną drobnych ukłuć politykę dostarczyliśmy bardzo licznego zastępu fanatycznych przeciw nam agitatorów w postaci setek inteligentnego i pół inteligentnego proletariatu ukraińskiego i rosyjskiego, wyrzuconego ryczałtowo z naszych urzędów bez najmniejszej korzyści dla Państwa, a przeciwnie z wielką dla niego szkoda. Proletariat ten, który tu odziedziczyliśmy w spadku po poprzednim rządzie rosyjskim, mogliśmy uczynić nieszkodliwym a w pewnej nawet części dla nas pożytecznym. My jednak wybraliśmy inną drogę: sami wytworzyliśmy wśród ludu tutejszego ten wrogi nastrój, który cisną go pod komendę przywódców 16, sami wytworzyliśmy sobie zastępy nieprzejednanych dziś wrogów, agitujących za listą Nr. 16.

Nasza polska racja stanu poszła na kresy wschodnie po linii „egoizmu narodowego". Stwierdzić należy, że, oprócz konserwatystów, zarazie tej uległy, „niestety, wszystkie stronnictwa demokratyczne i ludowe, działające na kresach wschodnich. Przyszliśmy na Wołyń z programem raptownej i brutalnej polonizacji wsi wołyńskiej za pomoca specjalnie spreparowanych ustaw/ ustawy sejmowe z d. 17 XII - 1920 r. ${ }^{17}$ i i okólników G.U.Z ${ }^{18}$, ograniczających w niedopuszczalny sposób i bezceremonialnie lud tutejszy w możności nabywania ziemi z parcelacji, za własny pieniądz, w celu zaokraglenia i doprowadzenia do stanu samowystarczalności swoich karłowatych gospodarstw rolnych. Gdybyż przynajmniej, przejmując ziemię na osadnictwo wojskowe, jednocześnie zastosowano właśnie w jak najszerszym zakresie umożliwienia

${ }^{17}$ Chodzi o ustawę związaną z przyznawaniem pożyczek dla ludności oraz o osadnictwie wojskowym. W każdym wypadku faworyzowani byli Polacy. Ustawa: http://prawo.sejm. gov.pl/isap.nsf/download.xsp/WDU19210040016/O/D19210016.pdf (dostęp: 15 IV 2019); http://prawo.sejm.gov.pl/isap.nsf/download.xsp/WDU19210040018/O/D19210018.pdf (dostęp: 15 IV 2019).

${ }^{18}$ G.U.Z - Główny Urząd Ziemski. Instytucja ta miała zająć się przeprowadzeniem reformy rolnej w II RP. Faktycznie jednak „przeważyła ludowa koncepcja przymusu administracyjnego. Niepełnego odszkodowania i drobnej własności tworzonej ręką urzędnika państwowego". W efekcie to urzędnik decydował o przyznawaniu ziemi. Na wschodzie urzędnikami byli w większości Polacy, którzy dyskryminowali np. ludność ukraińska. Zob. K. Chylak, Polityka agrarna rzadu Władystawa Grabskiego w latach 1923-1925, „Acta Universitatis Lodziensis" 2005, t. LXXVIII, s. 50. 
chłopom tutejszym nabywania ziemi przez parcelację. Ostrze osadnictwa wojskowego byłoby w znacznym stopniu stępione przez jak najszerzej zastosowanie równouprawnienie w nabywaniu parcelującej się ziemi dworskiej. My jednak uczyniliśmy inaczej i niesprawiedliwość, postanowioną w imię źle czy dobrze zrozumianej idei państwowej t. j. przejęcia ziemi pod osadnictwo wojskowe pogłębiliśmy przez drugą niesprawiedliwość, przez okólniki G.U.Z.

Nie tu miejsce na wszechstronną krytykę tego programu agrarnego, z jakim przyszliśmy na Wołyń. Poprzestajemy jedynie na stwierdzeniu, że obydwa te akty państwowe maja charakter wybitnie wyjątkowy, skierowany przeciw miejscowej ludności, a sposób ich przeprowadzenia jest jaskrawy, prowokujacy, nie liczący się z żadnymi względami.

Zastosowawszy te dwie reformy, mające na celu przekazanie jak największej ilości ziemi przybyszom z Polski, zarówno cywilnym, jak wojskowym, reformy o charakterze wybitnie wyjątkowym i skierowanym przeciw najżywotniejszym interesom miejscowej ludności, gdybyśmy byli konsekwentni w zastosowaniu metod działania do jego celów, nie mieliśmy prawa przeprowadzenia tak długo unifikacji ziem kresowych, jak długo ten gwałt polityczny, wywołany przez wyższą rację stanu, miał trwać. Należało wprzód program ten całkowicie i pomyślnie wykonać, a dopiero później przeprowadzić unifikację. Wymagała tego logika rządzenia. Jeżeli mieliśmy tu prawem zdobywcy przeprowadzić polonizację wsi wołyńskiej, przekazując ziemię osadnikowi polskiemu i pozbawiając jej tutejszego chłopa, mającego do niej bezsprzeczne pierwszeństwo, to nie można było nadawać Wołyniowi ogólnej Konstytucji, rozciagać na jego obszar równouprawnienia obywatelskiego i łagodzić form rządu, wreszcie doprowadzać do wyborów na zasadzie ogólnej ordynacji wyborczej do ciał prawodawczych i nadawać samorządów powiatowych.

Czyniąc w imię pewnych konieczności narodowo-państwowych coś takiego, co się sprzeciwia równości obywatelskiej i sprawiedliwości, nie można obywatelom, przeciw którym się działa, pozostawiać swobodnej możności organizowania się, bo trzeba rozumieć, że się zorganizują wyłącznie przeciw Państwu. Należało więc konsekwentnie pozostawić zarząd cywilno-wojskowy, o silnej lecz twórczej władzy, rodzaj generał gubernatorstwa. Pozorów i powodów do tego nie brakowało: były bandy zbójeckie, były i sa „Zakordoty”"19, było i jest bardzo dużo elementów po bolszewickich.

Przedwczesne dobrodziejstwo unifikacji przy równorzędnem stosowaniu ustaw wyjątkowych w najżywotniejszej dziedzinie reform agrarnych mogło

19 „Zakordot” - skrócona forma od rosyjskiego „Zakordonnyj Otdieł”. Była to sowiecka organizacja szpiegowska, która prowadziła działalność wywrotową na całym pograniczu polsko-sowieckim. Jej cele stanowiły dyskredytacja władz polskich oraz pozyskanie ludności ukraińskiej oraz białoruskiej. „Zakordot” posiadał swoje ekspozytury w Mińsku, Smoleńsku oraz w Kijowie. Organizacja prowadziła tzw. wywiad płytki, rozpracowywali np. strażnice Korpusu Ochrony Pogranicza. Zob. https://naszeblogi.pl/40675-szpiedzy-stalina-w-polsce (dostęp: 15 IV 2019). 
dać jedynie takie rezultaty, jakie dały tylko co ukończone wybory: skonsolidowanie się tutejszego ludu przeciw państwowości polskiej i karnego pójścia pod komendę przywódców listy Nr. 16.

Prócz tych dwóch najkardynalniejszych aktów niesprawiedliwości za strony Państwa w stosunku do miejscowej ludności, popełniliśmy tu cały szereg czynów, które nazwę czynami „Ancien regim'u” ${ }^{20}$ w najgorszym stylu, zaczęliśmy mianowicie stosować politykę rewanżu narodowego i religijnego, t. j. zasadę najgorszą i w każdym razie wymagająca do swojego przeprowadzenia takiej siły brutalnej, jaka stosowali Rosjanie w Kongresówce, a prusacy - w Poznańskiem, nie zaś rządów konstytucyjnych przy pomocy których ma chcieliśmy zasady te przeprowadzić. Raz tu jeszcze muszę wspomnieć o wysoce szkodliwym ryczałtowym ostracyzmie z naszych urzędów fachowych wszystkich dawnych funkcjonariuszy b. Zarządu Cywilnego Ziem Wołynia i Frontu Podolskiego ${ }^{21}$ narodowości ukraińskiej i rosyjskiej. Pod tym względem w znacznym stopniu przekroczyliśmy zasady, jakie stosował na dawnych „kresach zachodnich” rząd rosyjski, który wyrzucił w końcu z urzędów prawie wszystkich Polaków, czynił to jednak po r. 1863 stopniowo, na dystansie lat 30.

W dziedzinie szkolnictwa powszechnego popełniliśmy tu z jednej strony cały szereg aktów nietolerancji narodowościowej, z drugiej - wpuściliśmy do szkółek wiejskich najbardziej wrogi żywioł z Galicji Wschodniej, zamiast wykorzystać dawnych nauczycieli ludowych narodowości rosyjskiej, znaczacych jednak język miejscowy i mogących w nim wykładać.

W dziedzinie kultury nie zrobiliśmy nic absolutnie, wskutek czego z porównania z dawną gospodarką rządu rosyjskiego i ziemstw wyszliśmy w świetle bardzo ujemnem.

Jeżeli do tego wszystkiego dodamy gwałtowny upadek naszej waluty, podrywający zaufanie do siły państwowej, to przyznać musimy, że w okresie ubiegłych dwóch lat, poprzedzajaccych wybory, uczyniliśmy wszystko, aby obecnemu nastrojowi ludności usłać szerokie podłoże.

W warstwach ludowych musiało w takich warunkach odegrać decydujacca rolę hasło Nr. 16 „Wsia ziemla trudowomu sielanstwu”22, co jest jednak mniej niebezpiecznem, niż ta solidarność i karność, z jaką lud tutejszy poszedł pod komendę, wrogich nam przywódców. Świadczy to o tem, że w razie wydania innej komendy, takiej, której za wszelką cenę winniśmy uniknąć, lud tutejszy z równą karnością może się tej komendzie poddać. Komenderuje sproletaryzowana przez nas inteligencja i pół inteligencja miejska i wiejska, która pozbawiliśmy wszystkiego, prócz prawa swobodnego przeciw Polsce agitowania.

\footnotetext{
${ }^{20}$ Synonim reżimu, władzy tyranów.

${ }^{21}$ Zarząd Cywilny Ziem Wołynia i Frontu Podolskiego - organizacja administracji cywilnej, wydzielona 17 I 1920 r. z Zarządu Cywilnego Ziem Wschodnich. Przestał istnieć 9 IX 1920 r.

22 „Cała ziemia pracującemu chłopstwu”.
} 
Nie zastosowaliśmy tylko jednego wzoru dawnych carskich rządów w Polsce, właśnie najlepszego i godnego naśladowania. Rząd carski w Kongresówce pozyskał sobie na ogół chłopa i uczynił z niego najlojalniejszego w całem Imperjum poddanego, wierzącego święcie w potęgę Rosji i w siłę rządu. Doszedł do tego rezultatu przez uwłaszczenie ${ }^{23}$ i przez zastosowanie do ludu rządów silnych, chytrze skombinowanych. Modernizując ten system, można by i należało by z chłopa wołyńskiego uczynić zupełnie lojalnego obywateli i ślepego wykonawcę woli rządu.

My wszyscy, którzy pracowaliśmy dziesiątki lat nad wyrwaniem naszego chłopa z objęć lojalizmu carskiego, wiemy doskonale, ja trudno było wyrwać go z objęć tych, jak znakomicie rząd odgrodził chłopa od wszelkiej agitacji ideowej.

Oto główne przyczyny takiego klęskowego wyniku wyborów do Sejmu Prawodawczego na Wołyniu. Wyniki te stwierdzaja najwymowniej, że tu się szykuje dla Rzeczypospolitej wielka groźba. To nie jest przesada, to jest poważna i oparta na wymownych objawach troska, że w razie walki z wrogiem zewnętrznym, będziemy tu mieli gotowego wroga wewnętrznego, który tak samo karnie pójdzie pod komendę agitacji przeciwpolskiej, jak poszedł pod nia przy tylko co ukończonych wyborach. Działalność nasza na Wołyniu stwierdza, że zamiast zdobywać dla Polski lojalnych obywateli, zdobywamy dla Niej z roku na rok - wrogów.

Co do naszego systemu polonizacji Wołynia w drodze państwowego kolonizowania wsi, to droga ta okazuje się najwidoczniejszym błędem politycznym, co było do przewidzenia. Kosztem wytworzenia nieubłaganej nienawiści tutejszego ludu, wysnutej z poczucia krzywdy, powiększymy ludność polska o jakieś 3-4\%. Ludność ta rozproszona wśród tubylców, nie będzie stanowiła niewzruszonej ostoi polskości, w wielu przypadkach podda się wpływowi otoczenia i ulegnie mu. Jest rzeczą sprawdzona, że w wielu obwodach wyborczych polscy osadnicy głosowali na listę Nr. 16, nie chcąc się przeciwstawiać woli ogółu. Chłop polski, który tu się osiedla, chce zgodnego współżycia, a mając poczucie krzywdy, wyrządzanej tubylcowi, woli mu ulegać. Wspólność interesów chłopskich będzie tu zawsze większa, niż samowiedza państwowa chłopa polskiego.

Inną drogą musi pójść nasz pokojowy podbój kresów wschodnich, przedewszystkiem przez miasta, przez tworzenie silnych twierdz polskości i silnych ognisk cywilizacyjnych, kulturę polska, która by promieniowała i przyciagała. Nie inaczej odbywał się proces niemczenia Czech, Śląska, Pomorza, a nawet

${ }^{23}$ Nadanie ziemi chłopom w Kongresówce przeprowadzono w 1864 r. na mocy dekretu cara Aleksandra II. Projekt reform uwłaszczeniowych został opracowany przez Nikołaja Milutina. Zob. M. Kostrzewska, Pouwłaszczeniowy ruch chłopski - podobieństwa i różnice z ruchem antyfeudalnym, „Acta Universitatis Lodziensis” 1995, t. LII. Warto zwrócić też uwagę na kwestię ludnościową na wsi w Kongresówce. Zob. J.K. Janczak, Struktura społeczna wsi w Królestwie Polskim, „Acta Universitatis Lodziensis” 1992, t. XLV. 
Poznańskiego. Lud, który chce zapewnić swoim następnym pokoleniom wyższy szczebel społeczny, sam ciagnie do wyższej kultury narodowości, dominującej w państwie, przedwszystkiem ze względów oportunistycznych. W ten sposób, prócz siły brutalnej, zniemczyli prusacy Ślask i gdyby nie wielki przewrót dziejowy, w którym skruszyła się moc naszych ciemiężców, w wielu prowincjach dzisiejszej Polski proces wynaradawiania się ludu polskiego byłby nieubłaganie postępował naprzód.

Wreszcie mamy wyborne przykłady w Wilnie i Lwowie. Za tym przykładem winniśmy tworzyć silne ogniska kulturalne i twierdze polskości na Wołyniu przedewszystkiem w miastach, z Łuckiem na czele. Tylko kultura polska, tylko wielkie ogniska przemysłu polskiego, wysoko postawionej oświaty polskiej i sztuki, tylko przez dobrobyt, dający się osiagnać przez kulturę polską dokonamy dzieła najważniejszego: pokojowego zjednoczenia kresów z macierza polską.

\author{
/-/ K. Waligórski ${ }^{24}$ \\ [Podpis odręczny] \\ Łuck, d. 21/XI 1922 r.
}

${ }^{24}$ Chodzi o Karola Waligórskiego (1870-1928). Urodził się w Rejowie (ówczesna gubernia kielecka). W 1888 r. ukończył gimnazjum w Kielcach, następnie podją studia w Warszawie. Studiów nie skończył, do 1914 r. pracował jako urzędnik w Zagłębiu Dąbrowskim. Lata 1915-1919 spędził w Kijowie. Do Łucka przyjechał z Sosnowca, gdzie pracował jako urzędnik kopalni Reden. Pisał również sztuki teatralne (autorską jednoaktówkę wystawiono 16 IX 1894 r.), z wykształcenia był finansistą i przedsiębiorca. Zajmował się współpraca firm ze Ślasska i Wołynia. W 1919 r. brał udział w organizowaniu Wołyńskiej Izby Skarbowej. Współpracował z „Dziennikiem Wołyńskim”, na którego łamach opublikował wiele artykułów o życiu polityczno-społecznym Wołynia. Był zwolennikiem Piłsudskiego. Pełnił funkcję prezesa Związku Ziemian Wołynia (1921-1922). Sprawował urząd burmistrza Łucka (2 II 1923 - 1 XII 1923). Następnie objął urząd burmistrza w Kowlu. Był w konflikcie z ks. Feliksem Sznarbachowskim oraz wojewodą wołyńskim Aleksandrem Dębskim (polityk o orientacji nacjonalistycznej). W 1928 r. zmarł na atak serca. Zob. https://nto.pl/ moje-kresy-prezydenci-lucka/ar/9289217 (dostęp: 16 IV 2019); „Głos Wołyński”, 11 VI 1922; „Dziennik Urzędowy Województwa Wołyńskiego”, 6 VII 1923, s. 6, Sprawozdanie z konferencji zwołanej przez p. Wojewodę Srokowskiego w dniu 22 czerwca 1923 r. w sprawie stanu kolejnictwa na Wołyniu; https://www.kuriergalicyjski.com/index.php/redakcjapoleca/2851-dr-boles-aw-zieli-ski-pierwszy-prezydent-ucka-cz-i (dostęp: 16 IV 2019); J. Stobniak-Smogorzewska, Osadnictwo na Wołyniu 1921-1940, „Niepodległość i Pamięć” 2008, nr 15/1 (27), s. 155; https://sbc.org.pl/Content/214482/tradycje\%20teatru.pdf (dostęp: 16 IV 2019); W. Mędrzecki, Inteligencja polska na Wotyniu w okresie międzywojennym, Warszawa 2005, s. 50 (w publikacji tej autor podał błędnie, że Waligórski został burmistrzem Łucka w 1921 r.). Na rok 1923 wskazał ten historyk w pracy Województwo wotyńskie..., s. 136. 